\title{
Well - Lit : Penciptaan Game Mix-Genre Adventure Puzzle 2D
}

\author{
Laila Hafidhotul Khoiriyah \\ Program Studi Animasi, Fakultas Seni Media Rekam, \\ Institut Seni Indonesia Yogyakarta \\ e-mail: lailahafidhotul@gmail.com
}

\begin{abstract}
Abstrak
Smartphone saat ini menjadi trend yang mewabah di seluruh dunia karna terdapat featur dan interface menarik yang ditawarkan, seperti sistem oprasi Android. Kelebihan sistem oprasi Android sendiri yaitu menyediakan platform terbuka atau yang biasa disebut sebagai open source, bagi para pengembang untuk menciptakan berbagai jutaan aplikasi mereka sendiri yang nantinya akan dipergunakan untuk berbagai macam mobile device. Hal inilah yang menyebabkan perkembangan aplikasi game mobile phone berbasis Android sangat cepat.

Salah satu jenis game yang populer adalah platformer. Ada banyak sekali game platformer yang sangat laris bahkan melegenda seperti game Super Mario Bros. Sayangnya belum banyak game platformer original buatan Indonesia yang beredar di pasar aplikasi Android dikarnakan kebutuhan resource game yang banyak. Pasar aplikasi game Android di Indonesia didominasi oleh game jenis casual.
\end{abstract}

Kata kunci: Well-Lit, game, platformer, fantasy.

\begin{abstract}
Smartphone is currently a trend that is prevalent throughout the world because there are featur and attractive interfaces are offered, such as the operating system Android. Excess own Android operating system that provides an open platform or commonly referred to as open source for developers to create their own variety of millions of applications that will be used for a wide range of mobile devices. This has led to the development of applications based on the Android mobile phone game very quickly.

One popular type of game is a platformer. There are so many bestselling platformer game even a legend like the game Super Mario Bros. Unfortunately not many original platformer game made in Indonesia in the market Android dikarnakan resource needs that many games. Android game apps market in Indonesia is dominated by the kind of casual game.
\end{abstract}

Keywords: Well-Lit, game, platformer, fantasy. 